\title{
Changes in organic carbon concentration and organic matter compound of erosion-delivered soil aggregates
}

Article in Environmental Earth Sciences · January 2016

DOI: $10.1007 /$ s12665-015-5052-9

CITATIONS

0

9 authors, including:

\section{Gergely Jakab}

Hungarian Academy of Sciences

65 PUBLICATIONS 142 CITATIONS

SEE PROFILE

\section{Zoltán Szalai}

Hungarian Academy of Sciences

72 PUBLICATIONS 191 CITATIONS

SEE PROFILE
READS

64

Some of the authors of this publication are also working on these related projects:

USE OF STRUCTURAL SOIL PROPERTIES FOR IMPROVING PREDICTION METHODS IN SOIL SYSTEMS WETTING BY WATER OR NON-POLAR LIQUIDS View project

Renewable Energy and Landscape Quality (RELY) (2015-2018, COST Action TU1401, Horizon 


\section{Changes in organic carbon concentration and organic matter compound of erosion-delivered soil aggregates}

Gergely Jakab $1, *$

Email jakabg@mtafki.hu

Judit Szabó 2

Zoltán Szalai 1,2

Erzsébet Mészáros 1

Balázs Madarász 1

Csaba Centeri 3

Boglárka Szabó 3

Tibor Németh 4

Péter Sipos 4

${ }^{1}$ Geographical Institute RCAES, HAS, Budaörsi út 45, 1112 Budapest, Hungary

2 Department of Environmental and Landscape Geography, Eötvös Loránd University, Pázmány Péter sétány 1/C, 1117 Budapest, Hungary

3 Department of Nature Conservation and Landscape Ecology, Szent István University, Páter Károly u. 1., 2100 Gödöllö, Hungary

${ }^{4}$ Institute for Geochemical Research RCAES, HAS, Budaörsi út 45, 1112 Budapest, Hungary

\section{Abstract}


Soil organic carbon (SOC) is a key property for both fertility and carbon level control in the atmosphere. SOC changes in soils are ruled by tillage and erosion. Initial SOC erosion was investigated using a laboratory rainfall simulator. Six precipitation events were modelled on cultivated, bare Cambisol monolith with various slope steepness and surface roughness under a constant intensity of $80 \mathrm{~mm} \mathrm{~h}^{-1}$. The total amount of soil loss was divided into four aggregate size classes $(<0.05,0.05-0.25$, $0.25-1.00,>1.00 \mathrm{~mm}$ ). Altogether, 72 sediment and 16 in situ samples were analysed. The results show a loss of SOC concentration that increased at all aggregate sizes, the highest $(\sim 200 \%)$ found in the smallest grain size, while conversely nitrogen concentration decreased in the 250-1000 $\mu \mathrm{m}$ class. Consequently, soil organic matter (SOM) compounds underwent changes during the initial erosion processes in soil losses of all aggregate sizes. The detached SOM was less polymerised and had more aromatic character compared to that of the in situ soil in all aggregate size classes. The type of SOM enrichment found through the soil loss in this study is a result of two parallel processes within initial erosion phenomenon: (I) chemical degradation of the most labile SOM components and (II) mineralogical changes in the smallest aggregate class $(<0.05 \mathrm{~mm})$ that results in a considerable amount of quartz leaving the aggregates and remaining on the surface. The results suggest that tillage operations regarding stability of the smallest aggregates have particular importance in SOC conservation.

\section{AQ1}

AQ2

\section{Keywords}

Selective erosion

Conventional tillage

Soil organic carbon redistribution

Subhumid climate

Rainfall simulation

Cambisol

\section{Introduction}

Information on global carbon cycle becomes increasingly important 
because of the expanding effects of climate change (Davidson and Janssens 2006; Le Quéré et al. 2009). Soil organic carbon (SOC) concentration ensures the fertility, structure and good hydrological conditions of the pedosphere. The uppermost one-metre layer of the soil has the second largest terrestrial carbon stock of $2500 \mathrm{Pg}$, which is twice higher than that of the biosphere and the atmosphere combined (Stockmann et al. 2013). From qualitative and quantitative aspects, this stock is an ever-changing system (Bellamy et al. 2005), as SOC can migrate, transform, be sequestrated or released as a result of the current effects of biological, physical and chemical processes. Most soils cannot reach its potential carbon storage capacity mainly due to intensive tillage operations (Ye et al. 2015 ). The low level of SOC saturation means that pedosphere can be a sink for atmospheric $\mathrm{CO}_{2}$ (Liu et al. 2011). Even minor changes in carbon sequestration by soils can cause very rapid and remarkable variation of carbon concentration in the atmosphere (Lal 2004a). These changes can be made by optimised land management and land-use structure (Noponen et al. 2013; Su et al. 2013). Increasing carbon sequestration in soils has two environmental benefits: (I) it can be a powerful tool to improve net removal of atmospheric $\mathrm{CO}_{2}$ and (II) it improves soil fertility and water management (Freibauer et al. 2004; Quinton et al. 2010). In addition to SOC oxidisation due to tillage (Häring et al. 2013), accelerated soil erosion is the other main trigger of SOC redistribution (Lal 2004b; Tang and Guan 2014). Recently, soil erosion is assumed to have more carbon sequestering effects than carbon releasing in terms of the global carbon cycle (Wang et al. 2015); however, SOC erosion is a rather complex process driven by several local environmental conditions (Van Oost et al. 2007 ). In soils, SOC manifests as soil organic matter (SOM) which is a mixture of organic molecules of various size and composition. Labile SOM has a very fast turnover rate ( $<5$ years) and serves as nutrition for the biomass, while the turnover rate of inert SOM parts can exceed a millennium (Verma et al. 2013). Additional widely applied methods for SOM characterisation are based on molecular size and carbon/nitrogen $(\mathrm{C} / \mathrm{N})$ ratio determination (Kahle et al. 2013).

Although several studies deal with the variation of SOC concentration and SOM compound in aggregates of different size in cultivated topsoil (Rabbi et al. 2014; Spaccini and Piccolo 2013), still little is known about the processes of redistribution due to erosion (Wiaux et al. 2014). Basic particle size relations to SOM compound were studied by Tisdall and 
Oades (1982). Micro-aggregates $(<0.25 \mathrm{~mm})$ are believed to be associated with the stable inert SOM, while macro-aggregates contain the labile more reactive SOM. Moreover, stable SOM parts tend to be of high molecular weight and low $\mathrm{C} / \mathrm{N}$ ratio and vice versa. On the other hand, SOM stability is not just a question of molecular composition but rather environmental, biological and physical availability for decomposition by microbes (Schmidt et al. 2011). Accordingly, various types of soil aggregates are prone to different types of SOC decrease. While on sandy soils with low aggregate stability the ratio of particular and dissolved carbon loss by erosion is dominant, clay soils with high aggregate stability and SOC concentration lose their SOC mainly by $\mathrm{CO}_{2}$ gas emissions due to decomposition (Chaplot and Cooper 2015).

Various SOM compounds have different roles in providing soil fertility and shaping soil structure that is why it is essential to emphasize that initial soil erosion is a selective phenomenon in terms of SOC concentration and SOM compound (Farsang et al. 2012; Wang et al. 2010). However, this selectivity is not clearly understood under certain circumstances (various soil types, cultivation methods, crop rotation, climate conditions, etc.). Aggregate breakdown can release formerly protected SOM components from aggregates that due to their low density are much more easily erodible than other soil components (Schmidt et al. 2011 ). On the other hand, soil delivery by runoff is also a complex process which leads to considerable differences among the properties of the detached soil particles affected by the delivery process and of the deposited sediment (Van Oost et al. 2007). This difference could be decisive for the carbon redistribution on arable fields. Aggregate distribution of the in situ soil and the soil loss accordingly differs from each other since aggregates are influenced not only by splash erosion but delivery processes as well.

According to our hypothesis based on the state of the art, the aggregate distribution and the SOC, SOM and mineralogical distribution in the aggregates change due to initial erosion and sediment delivery. This study aims (I) to detect the physical manifestation of SOC enrichment in the various sized aggregates delivered by surface runoff, (II) to detect changes in SOM compound of the different aggregates and (III) to compare the mineralogical composition of the in situ and detached aggregates. 


\section{Materials and methods}

\section{Study site}

The examined soil is the uppermost intensively tilled layer of an eutric calcaric Cambisol loamic (WRB 2007) on sandy loess parent material. It is located at Ceglédbercel, Hungary $\left(47.249846^{\circ} \mathrm{N} ; 19.678744^{\circ} \mathrm{E}\right)$ (Fig. 1). The elevation is between 154 and $170 \mathrm{~m}$ a.s.l., mean annual temperature is $10.8^{\circ} \mathrm{C}$, while annual precipitation is around $600 \mathrm{~mm}$ (Dövényi 2010).

\section{Fig. 1}

Location of the study site; arrow indicates the sampling point for rainfall simulation (GoogleEarth)
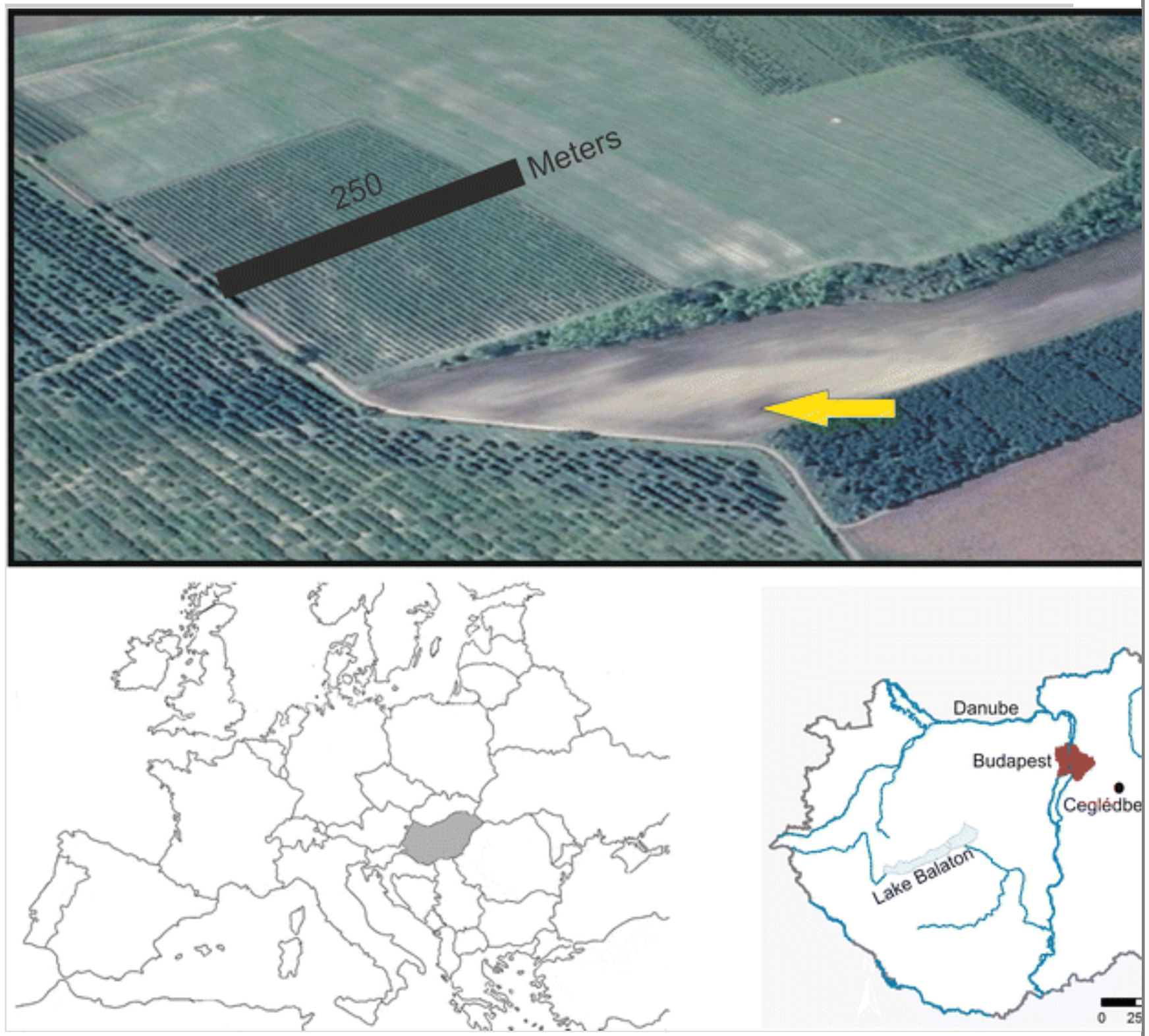

The studied field is 3.2 ha, hardly affected by tillage and accelerated erosion. It has been cultivated since the early 1700 s. The cultivation 
method applied is conventional tillage with autumn mouldboard ploughing. Prevalent crops for the last decades are winter wheat, maize and sunflower. The steepest parts are eroded to the parent material, while on the lower section deposited humic layers can be found with a depth of $3 \mathrm{~m}$. The average slope steepness is $12 \%$.

\section{Rainfall simulation}

For soil detachment investigations, a laboratory rainfall simulator was used. The equipment is able to measure infiltration into, runoff and soil loss from, a monolith of $0.5 \mathrm{~m}$ width, $1 \mathrm{~m}$ length and $0.2 \mathrm{~m}$ depth. The first version of the rainfall simulator was designed and constructed by Zámbó and Weidinger (2006). In recent years, it was equipped with $1 / 2 \mathrm{HH} 40$ WSQ fulljet nozzle which produces $1.95 \mathrm{~mm}$ median drop size diameter with an energy of $17 \mathrm{~kJ} \mathrm{~m}^{-2} \mathrm{~mm}^{-1}$ under $20 \mathrm{kPa}$ pressure (Strauss et al. 2000 ). That results in a constant rainfall intensity of $80 \mathrm{~mm} \mathrm{~h}^{-1}$.

Consequently, each experiment was treated by a constant intensity of $80 \mathrm{~mm} \mathrm{~h}^{-1}$.

In the fall of 2013 right after the regular tillage operations (mouldboard ploughing) soil was sampled. The recently ploughed soil was taken from the tillage depth $(18 \mathrm{~cm})$ into transporting bags and was carried to the laboratory. The case of the simulator was filled by the transported soil immediately after the arrival to the laboratory. The soil was pre-treated by $80 \mathrm{~mm}$ artificial rainfall of a constant intensity of $80 \mathrm{~mm} \mathrm{~h}^{-1}$ in a perfectly horizontal position in order to redistribute the soil particles and fill the gaps on the surface. This tilled soil monolith was used for each measurement. Altogether, six precipitation events were applied on bare surface under 2, 5 and $12 \%$ slope steepness both on recently tilled and crusted surface. Crust was induced by the first artificial rainfall on a tilled surface. After the measurement on the crusted surface, hoeing was carried out in the uppermost 5-cm-thick layer in order to model disking.

Measurements were always carried out in condition of soil water content at field capacity. In all cases, the total amount of runoff was collected and separated by sieve series. In this way, the whole amount of soil loss was divided into four aggregate size fractions as follows:

class 1: $>1 \mathrm{~mm}$,

class 2: $1-0.25 \mathrm{~mm}$, 
class 3: $0.25-0.05 \mathrm{~mm}$,

class 4: $<0.05 \mathrm{~mm}$.

The original, in situ, tilled soil was also separated with the same sieve series using an under-water level method (Kemper and Rosenau 1986) as a control. Control sieving was done in four repetitions. Altogether, 72 soil loss samples and 16 control samples were collected and analysed. One soil sample was measured three or four times parallelly in order to establish a statistically stable database which contains more than 250 items of separate measurements. Database was analysed by one-way ANOVA with Tukey test in SPSS 14 environment. Further details regarding the rainfall simulation studies are reported by Szabó et al. (2015). In the present study, only the summarized results figure independently from the varying slope and initial moisture conditions.

\section{Laboratory support}

Soil and sediment samples were analysed by a carbon-nitrogen analyser (Tekmar Dohrman Apollo 9000N) in order to measure the SOC and total nitrogen (TN) concentration (Buurman et al. 1996). $\mathrm{C} / \mathrm{N}$ ratio was used to predict the degree of polymerisation of the SOM. For additional SOM characterisation, UV-Vis spectrophotometry (Shimadzu 3600) was used in case of the soil losses of the "crusted surface on $12 \%$ slope (12C)" treatment. SOM was released by $0.5 \mathrm{M} \mathrm{NaOH}$, then all the absorbance spectra were recorded between 200 and $800 \mathrm{~nm}$. Rating the functional group density and the molecular weight of the released $S O M E_{4} / E_{6}$ (ratio of absorbance values measured at 465 and $665 \mathrm{~nm}$ ), $E_{2} / E_{3}$ (ratio of absorbance values measured at 254 and $365 \mathrm{~nm}$ ) and Ultraviolet Absorbance Ratio Index (URI, UVA $210 / \mathrm{UVA}_{254}$ ) indexes were calculated (Tan 2003; Her et al. 2008). Lower index values indicate higher degree of polymerisation and vice versa. For the prediction of SOM aromaticity, the absorbance values at $280 \mathrm{~nm}$ were applied which are proportional to the density of aromatic characters (Chin et al. 1994). Mineralogical characteristics of the samples were identified by X-ray diffractometry (XRD) performed on a Philips PW-1730 diffractometer using $\mathrm{CuK} \alpha$ radiation (applying an acceleration voltage of $45 \mathrm{kV}$ and a tube current of $35 \mathrm{~mA}$ ), at a data collection speed of $1 \mathrm{~s} / 0.052 \theta$. Elemental characteristic of the soil was characterized by wavelength-dispersive X-ray fluorescent 
spectrometer Phillips PW 1410 (XRF).

AQ3

Both soil $\mathrm{pH}$ in distilled water and in $\mathrm{KCl}$ were determined in a soil suspension 1:5 (Buurman et al. 1996). For water-soluble properties, a 1:10 solution was applied after 120-min agitation on a laboratory orbital shaker and filtration. Analytic measurements were done applying the following instruments: Jenway 3510 for $\mathrm{pH}$, and Jenway 4510 for alkalinity, conductivity and total and permanent hardness. Water-soluble ion concentrations were measured using a spectrophotometer (Shimadzu 1240) and a flame photometer (Sherwood 410) (Burt and Staff 2004).

\section{Results and discussion}

\section{In situ soil}

Main soil properties including major element composition measured by XRF are shown below (Table 1). According to the XRD analyses, the mineralogical composition refers to the dominance of quartz, primary and secondary silicates such as feldspars, mica, chlorite and swelling clay minerals (predominated by beidellite). Among other non-silicate minerals, the presence of calcite and dolomite is relevant. The considerable amount of $\mathrm{NO}_{3}{ }^{-}$and $\mathrm{SO}_{4}{ }^{2-}$ in the extraction refers to the high amount of watersoluble salts in the soil.

\section{Table 1}

Main properties of the investigated soil

\begin{tabular}{|c|c|c|c|c|c|c|}
\hline Property & Unit & Value & & $\begin{array}{l}\% \\
\left(\mathrm{~m} \mathrm{~m}^{-1}\right)\end{array}$ & SD & $\begin{array}{l}1: 10 \text { extract in } \\
\text { water }\end{array}$ \\
\hline Depth & $\mathrm{cm}$ & $0-20$ & & & & \\
\hline $\begin{array}{l}\text { Soil } \\
\text { particles }<0.002 \mathrm{~mm}\end{array}$ & $\begin{array}{l}\% \\
(\mathrm{v} v \\
-1)\end{array}$ & 10 & $\mathrm{Al}_{2} \mathrm{O}_{3}$ & 12.15 & 0.04 & Conductivity \\
\hline $\begin{array}{l}\text { Soil particles } 0.002- \\
0.02 \mathrm{~mm}\end{array}$ & $\begin{array}{l}\% \\
(\mathrm{v} v \\
-1)\end{array}$ & 74.7 & $\mathrm{MnO}$ & 0.11 & 0.01 & $\mathrm{pH}$ \\
\hline $\begin{array}{l}\text { Soil } \\
\text { particles }>0.02 \mathrm{~mm}\end{array}$ & $\begin{array}{l}\% \\
(\mathrm{v} v \\
-1)\end{array}$ & 15.3 & $\mathrm{MgO}$ & 1.89 & 0.04 & Alkalinity \\
\hline $\mathrm{CaCO}_{3}$ & $\begin{array}{l}\% \\
(\mathrm{v} v\end{array}$ & 5.1 & $\mathrm{CaO}$ & 5.23 & 0.04 & $\mathrm{HCO}_{3}^{-}$ \\
\hline
\end{tabular}




\begin{tabular}{|c|c|c|c|c|c|c|}
\hline & $\left.{ }^{-1}\right)$ & & & & & \\
\hline $\mathrm{SOC}$ & \multirow{2}{*}{$\frac{\mathrm{mg}_{\mathrm{kg}^{-1}}}{1}$} & 13,640 & $\mathrm{SiO}_{2}$ & 57.22 & 0.51 & $\begin{array}{l}\text { Total } \\
\text { hardness }\end{array}$ \\
\hline $\mathrm{TN}$ & & 213 & $\mathrm{P}_{2} \mathrm{O}_{5}$ & 0.33 & 0.00 & $\mathrm{Ca}^{2+}$ \\
\hline $\mathrm{C} / \mathrm{N}$ & & 64 & $\mathrm{TiO}_{2}$ & 0.66 & 0.01 & $\mathrm{Mg}^{2+}$ \\
\hline$E_{4} / E_{6}{ }^{*}$ & & 2.9 & $\mathrm{Fe}_{2} \mathrm{O}_{3}$ & 3.92 & 0.03 & $\begin{array}{l}\text { Permanent } \\
\text { hardness }\end{array}$ \\
\hline URI** & & 2 & $\mathrm{~K}_{2} \mathrm{O}$ & 2.54 & 0.02 & $\mathrm{Cl}^{-}$ \\
\hline Abs. at $280 \mathrm{~nm}$ & & 1.2 & & & & $\mathrm{NO}_{3}^{-}$ \\
\hline$E_{2} / E_{3} * * *$ & & 2.5 & & & & $\mathrm{SO}_{4}{ }^{2-}$ \\
\hline Colour & & $\begin{array}{l}10 \mathrm{YR} \\
3 / 3\end{array}$ & & & & $\mathrm{~K}^{+}$ \\
\hline $\mathrm{pH}$ (distilled water) & & 7.63 & & & & $\mathrm{Na}^{+}$ \\
\hline $\mathrm{pH}_{\mathrm{KCl}}$ & & 7.13 & & & & \\
\hline
\end{tabular}

$S O C$ soil organic carbon, $T N$ total nitrogen, $C / N$ ratio between the carbon and nitrc Abs. absorbance

* Ratio between the absorption values at 465 and $665 \mathrm{~nm}$

** Ultraviolet Absorbance Ratio Index, ratio between the absorption values at 210

*** Ratio between the absorption values at 254 and $365 \mathrm{~nm}$

The in situ soil is well aggregated with physically stable structure. SOC concentration of the original cultivated uppermost layer can be seen in Fig. 2 a. The smaller aggregate classes are homogeneous, but the class of aggregates larger than $1 \mathrm{~mm}$ has higher variance. In accordance with the results of Watteau et al. (2012) and Liu et al. (2014), macro-aggregates $(>0.25 \mathrm{~mm})$ have significantly higher SOC concentration than the smaller ones $(p<0.05)$; the difference is around $40 \%$. This surplus suggests a considerably higher volume of labile SOM that clamps micro-aggregates to bigger aggregates as it was reported by (Kuhn et al. 2012). Nevertheless, the highest SOC volume was found in the smallest fraction $(<0.05 \mathrm{~mm})$ 
which was more than twice higher than in the present case. The difference between the soils might be attributed to their distinct clay content.

Although SOC is presumed to create complexes with minerals, especially clay minerals (Hassink 1997), in this case the smallest size fraction has the lowest SOC concentration. Consequently, some significant part of the SOC rather prefers to bind with aggregates than to attach to single-clay minerals. Regarding the TN concentration, it is also true that aggregate size is proportional to nitrogen concentration, even though only the difference between the smallest and the biggest aggregate classes is significant $(p<0.05)$ (Fig. 2 b).

\section{Fig. 2}

Soil organic carbon (a) and total nitrogen (b) values in the four aggregate size groups in case of "in situ" soil as a control and soil loss
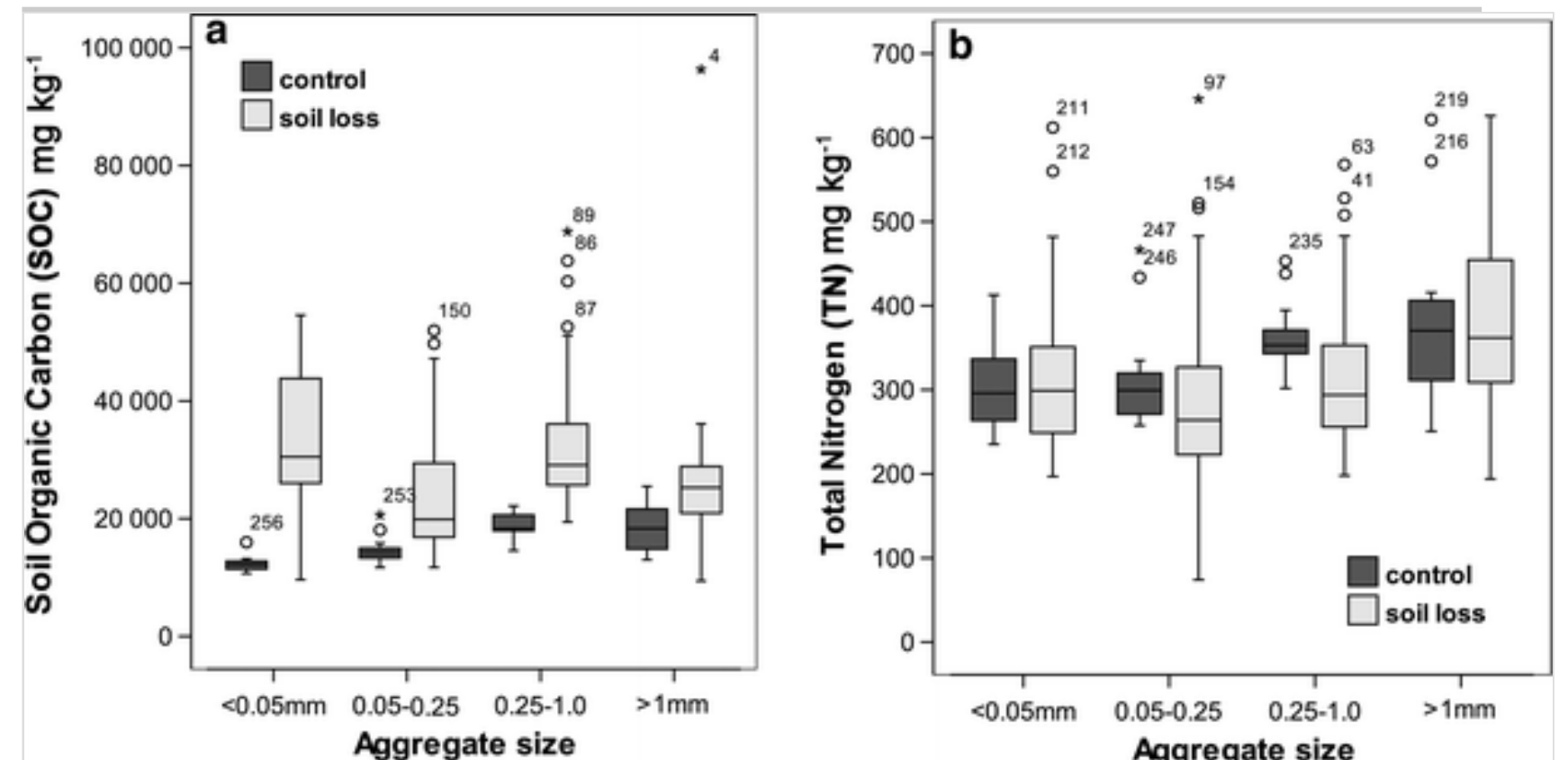

The difference of $27 \%$ is much lower than that in the case of SOC. This can refer to distinct $\mathrm{C} / \mathrm{N}$ ratios at different aggregate sizes, but no significant difference was found concerning $\mathrm{C} / \mathrm{N}$ ratios among the classes. The mean $\mathrm{C} / \mathrm{N}$ ratio value within groups however is proportional to aggregate size (Fig. 3 ) as it was presented also by Watteau et al. (2012). This suggests that the binding part among aggregates of SOM has a lower maturity degree than that of attended as organic-mineral complexes (Bronic and Lal 2005). In general, the presented $\mathrm{C} / \mathrm{N}$ ratio values are higher than those reported by Kahle et al. (2013) probably due to the dominance of fresh SOM, but similar to those presented by Yamashita et 
al. (2006). Regarding the spectrophotometric indexes, the aggregate size is proportional to aromaticity but there is no clear trend for the degree of polymerisation. Consequently, fresh SOM rules the physical properties of the soil that results in high ratio of non-complex SOM as a binding agent among aggregates (Shepherd et al. 2002).

\section{Fig. 3}

Organic carbon and nitrogen ratio values in the four aggregate size groups in case of "in situ" soil as a control and soil loss

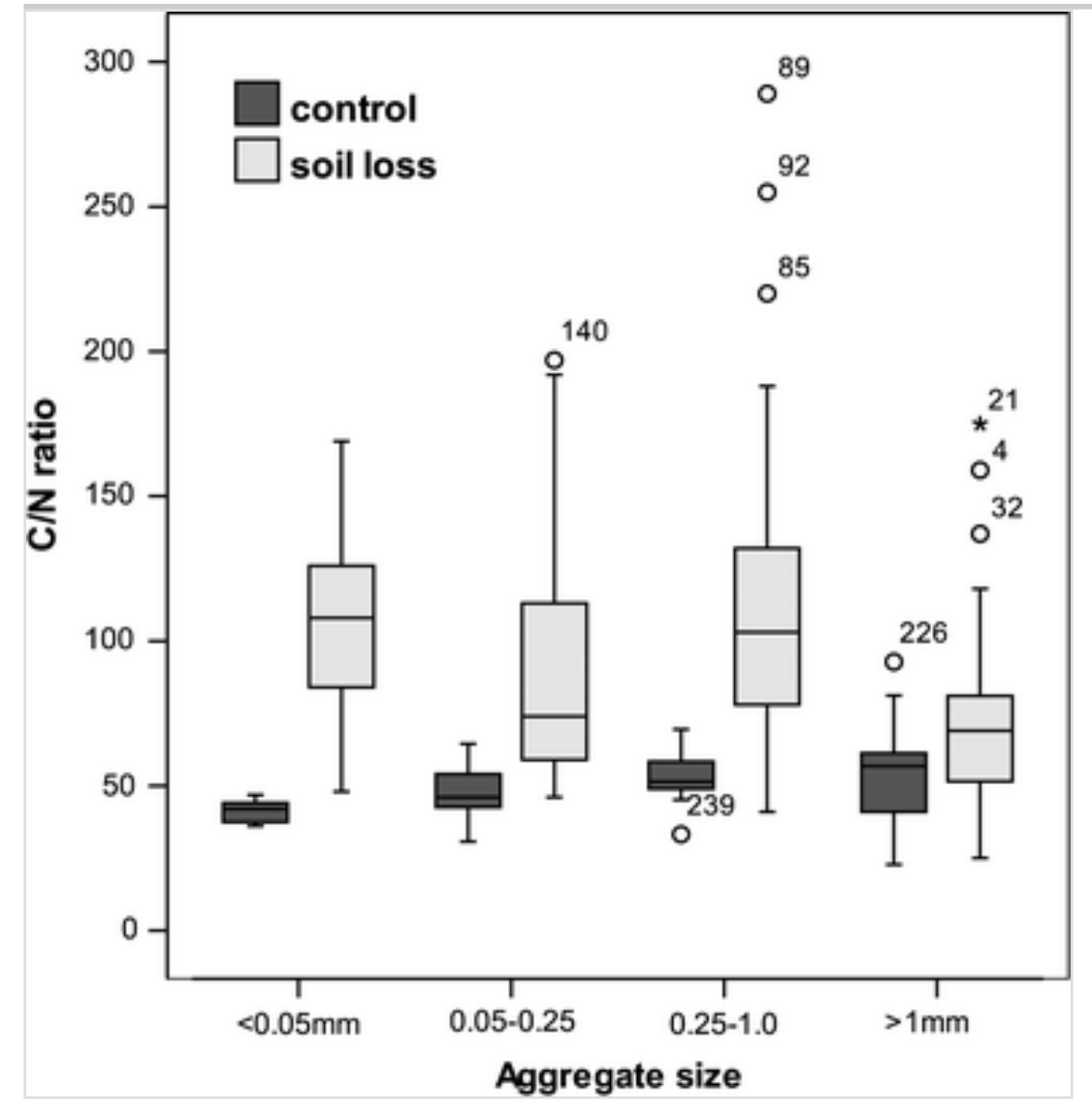

\section{Mean detached soil loss}

Summarizing all the soil losses collected from each precipitation, slope and surface roughness conditions, the variance of SOC and TN concentration appeared much higher (Fig. $2 \mathrm{a}, \mathrm{b}$ ). On the other hand, SOC concentration was significantly increased at each aggregate size class compared to the control values as it was also presented before (Farsang et al. 2012; Kuhn et al. 2012; Wang et al. 2010). High variance resulted in a significant SOC difference that was only found between the smallest and the biggest aggregates in soil loss $(p<0.05)$. The highest increase - almost twicewas found in the smallest particles, while the biggest aggregates had the lowest rise. SOC surplus found in the soil loss is a result of aggregates 
broken down on the surface by splash erosion (Jin et al. 2008). Beguería et al. (2015) found no significant SOC enrichment in the soil loss within the smallest grain size $(<0.05 \mathrm{~mm})$ due to splash erosion on Cambisol in Spain, while in the $0.05-0.50 \mathrm{~mm}$ fraction considerable SOC surplus was measured. The contradiction is based on distinct aggregate stability. More stable aggregates along with the lower raindrop impact triggered the difference in the class of smaller grain size.

Due to differences in specific weight, the mineral component of the aggregates remains on the surface, but the SOC concentration is able to join easily the runoff and soil loss. This presumably concerns the smallest clay particles as this class has the highest active surface. Jacinthe et al. (2004) presented results on the enrichment of this labile SOM in soil loss which is doubtlessly verified by our results.

In general, no significant difference was found between the TN concentration of the in situ soil and in each aggregate class of the soil loss. The original proportional trend between aggregate size and TN concentration still exists in soil loss; however, only the biggest macroaggregates have a significantly $(p<0.05)$ higher value compared to the smaller groups (Fig. 2b). The highest difference within a class was found in case of $0.25-1.00 \mathrm{~mm}$ aggregates $(p<0.05)$. Nitrogen loss in this class proves that the SOM concentration of these aggregates is not intact during splash erosion and delivery processes. Since SOC concentration increased while TN decreased, some sort of selective SOM exchange had to happen as it was also speculated by Kirkels et al. (2014).

SOM selectivity role of soil erosion is also demonstrated by the $\mathrm{C} / \mathrm{N}$ ratio characteristic of the aggregate classes. In each aggregate size class, soil loss has significantly higher $\mathrm{C} / \mathrm{N}$ values than in the in situ soil $(p<0.05)$ (Fig. 3 ). The highest mean value and the biggest difference were found in the smallest aggregate class where the value doubled. $\mathrm{C} / \mathrm{N}$ value over 100 presents a definitely mobile SOM with high acidity and low molecular weight. Since this type of SOM was not demonstrated in the in situ soil, chemical changes of SOM were supposed to happen during erosion processes. These chemical changes are presumed to appear as a degradation process of the unstable components of lower molecular weight that might increase the $\mathrm{C} / \mathrm{N}$ value. Probably, this stage of SOM degradation is the pre-oxidation phase. 
The smallest difference was measured between the in situ soil and the soil loss in the case of the biggest aggregates. While in the in situ soil the smallest aggregates have the most polymerised SOM, in the soil loss the biggest aggregates have the organic matter with the highest molecular weight. This suggests a direct relationship between SOM degradation and splash erosion. The most vulnerable components are reported to be found within the macro-aggregates (Tisdall and Oades 1982). The undamaged aggregate as a shelter can protect this SOM even during the whole delivery process.

In order to estimate the total amount and compound of SOC in the soil loss, aggregate size distribution has to be taken into account (Fig. 4). The in situ soil is characterized by the prevalence of macro-aggregates, whereas the smallest class has only a proportion of few percent. Conversely, the soil loss from the disturbed and crusted surface mainly contains particles less than $0.05 \mathrm{~mm}$ and there are almost no aggregates larger than $1.00 \mathrm{~mm}$. Soil loss from the recently tilled soil is in between with the highest share of aggregates of the $0.05-0.25 \mathrm{~mm}$ class.

\section{Fig. 4}

Aggregate size distribution in case of "in situ" soil as a control and soil losses from recently tilled and crusted surface

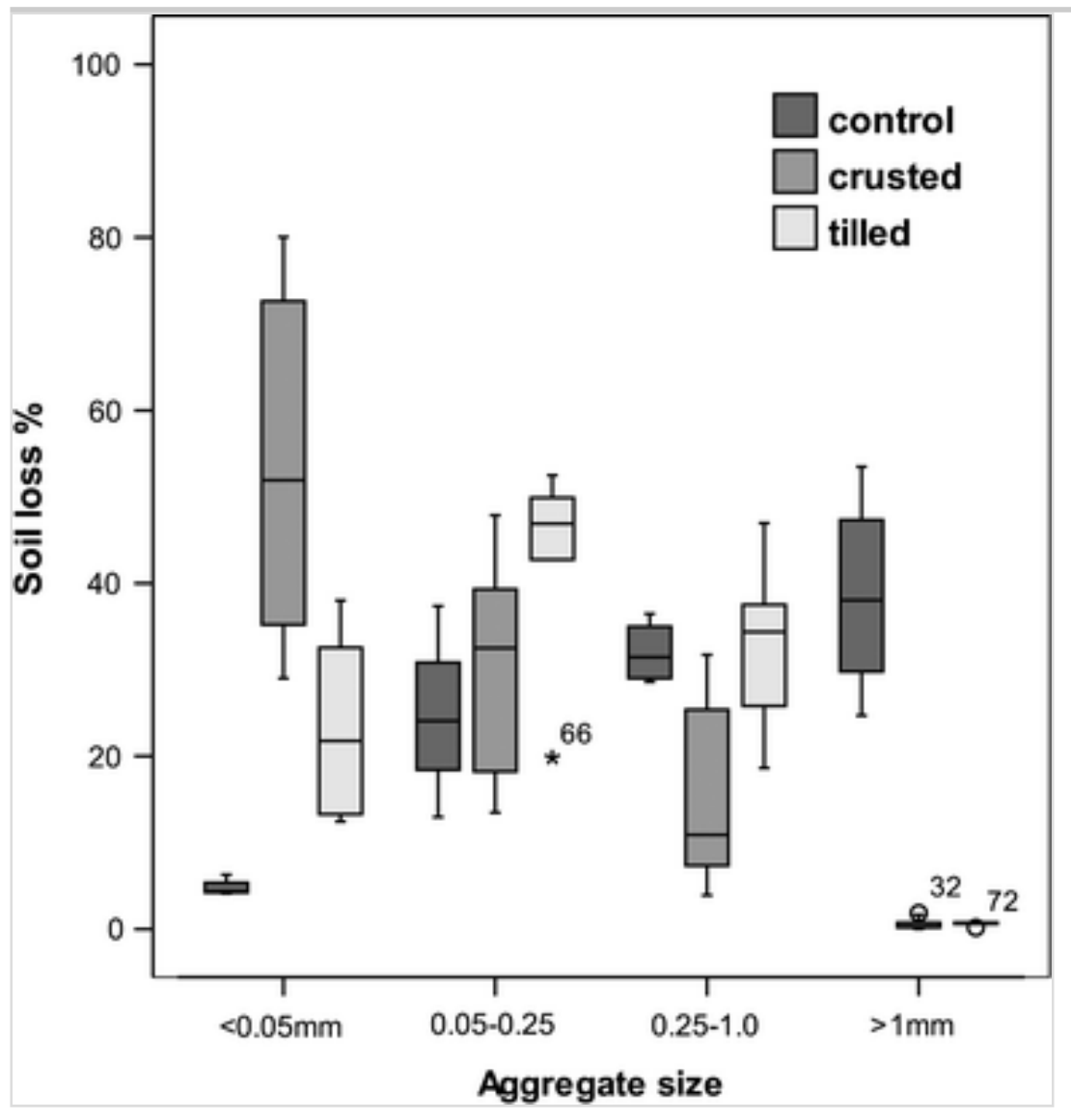


Consequently, splash erosion has an effective influence to break down aggregates. The difference in mean aggregate size between the soil loss and the crusted and tilled surfaces underlines the soil protecting role of crust; however, runoff volume increases considerably due to surface sealing (Szabó et al. 2015). Soil loss values multiplied by SOC concentration resulted in the net carbon loss (Table 2). In most cases, main carbon loss is related to micro-aggregates. The ratio between carbon delivered by micro- versus macro-aggregates varies in a wide range. In general, the values are higher than 1 that demonstrate the priority of stable SOM associated with micro-aggregates. On the other hand, the ratio does not exceed 2.2 on the $12 \%$ slope and on the recently cultivated $5 \%$ slope. Therefore, a considerable volume of labile SOM associated with macroaggregates in soil loss was only found under these treatments, even though this type of SOM is believed to be the fastest indicator of changes in SOC stock (Wen et al. 2013). The highest values were registered from the gentle slope due to the lack of macro-aggregates in soil loss there. Medium values were recorded in the crusted $5 \%$ slope case that suggests that protection role of surface crust provided by the macro-aggregates manifests only at slope angles of less steepness. Therefore, erosion from the steeper crusted surface has the most effective carbon enrichment in soil loss. There is no correlation of general changes in net carbon loss with the duration of a precipitation event.

\section{Table 2}

Net carbon losses from various treatments and aggregate classes (mg)

\begin{tabular}{|c|c|c|c|c|c|c|}
\hline & $5(\%) \mathrm{T}$ & $5(\%) \mathrm{C}$ & $12(\%) \mathrm{T}$ & $12(\%) \mathrm{C}$ & $2(\%) C$ & $2(\%) \mathrm{C}$ \\
\hline \multicolumn{7}{|l|}{ Period I } \\
\hline$>1.00 \mathrm{~mm}$ & $8.5(1.5)$ & $0.4(0.5)$ & $31.3(4.9)$ & $\begin{array}{l}17.5 \\
(1.1)\end{array}$ & NA & NA \\
\hline $\begin{array}{l}1.00- \\
0.25 \mathrm{~mm}\end{array}$ & $\begin{array}{l}652.0 \\
(127.5)\end{array}$ & $\begin{array}{l}136.4 \\
(17.9)\end{array}$ & $\begin{array}{l}1811.3 \\
(63.9)\end{array}$ & $\begin{array}{l}322.6 \\
(25.7)\end{array}$ & $\begin{array}{l}54.7 \\
(1.0)\end{array}$ & $\begin{array}{l}57.1 \\
(11.7)\end{array}$ \\
\hline $\begin{array}{l}0.25- \\
0.05 \mathrm{~mm}\end{array}$ & $\begin{array}{l}266.4 \\
(16.8)\end{array}$ & $\begin{array}{l}213.3 \\
(1.9)\end{array}$ & $\begin{array}{l}1730.9 \\
(220.2)\end{array}$ & $\begin{array}{l}229.6 \\
(17.2)\end{array}$ & $\begin{array}{l}469.0 \\
(33.8)\end{array}$ & $\begin{array}{l}101.9 \\
(26.5)\end{array}$ \\
\hline$<0.05 \mathrm{~mm}$ & $\begin{array}{l}422.0 \\
(35.2)\end{array}$ & $\begin{array}{l}347.6 \\
(12.6)\end{array}$ & $\begin{array}{l}1329.1 \\
(25.8)\end{array}$ & $\begin{array}{l}368.0 \\
(14.0)\end{array}$ & $\begin{array}{l}620.2 \\
(32.5)\end{array}$ & $\begin{array}{l}554.4 \\
(10.9)\end{array}$ \\
\hline
\end{tabular}

Period II 


\begin{tabular}{|l|l|l|l|l|l|l|}
\hline$>1.00 \mathrm{~mm}$ & $2.2(0.3)$ & $1.6(0.1)$ & $33.1(2.7)$ & $(0.9)$ & NA & NA \\
\hline $\begin{array}{l}1.00- \\
0.25 \mathrm{~mm}\end{array}$ & $\begin{array}{l}471.8 \\
(46.6)\end{array}$ & $\begin{array}{l}125.5 \\
(6.7)\end{array}$ & $\begin{array}{l}1481.1 \\
(97.6)\end{array}$ & $\begin{array}{l}337.9 \\
(11.6)\end{array}$ & $\begin{array}{l}50.2 \\
(2.7)\end{array}$ & $\begin{array}{l}49.1 \\
(22.4)\end{array}$ \\
\hline $\begin{array}{l}0.25- \\
0.05 \mathrm{~mm}\end{array}$ & $\begin{array}{l}501.0 \\
(77.0)\end{array}$ & $\begin{array}{l}291.5 \\
(82.2)\end{array}$ & $\begin{array}{l}1149.7 \\
(93.8)\end{array}$ & $\begin{array}{l}252.5 \\
(17.2)\end{array}$ & $\begin{array}{l}107.9 \\
(18.8)\end{array}$ & $\begin{array}{l}82.3 \\
(7.0)\end{array}$ \\
\hline \multirow{2}{*0.05\mathrm{mm}}{} & $\begin{array}{l}480.5 \\
(27.3)\end{array}$ & $\begin{array}{l}524.4 \\
(34.4)\end{array}$ & $\begin{array}{l}407.1 \\
(13.3)\end{array}$ & $\begin{array}{l}247.8 \\
(44.3)\end{array}$ & $\begin{array}{l}787.8 \\
(24.6)\end{array}$ & $\begin{array}{l}499.2 \\
(17.5)\end{array}$ \\
\hline
\end{tabular}

Period III

\begin{tabular}{|l|l|l|l|l|l|l|}
\hline$>1.00 \mathrm{~mm}$ & $6.9(0.4)$ & NA & $43.9(7.1)$ & $\begin{array}{l}28.9 \\
(4.1)\end{array}$ & NA & NA \\
\hline $\begin{array}{l}1.00- \\
0.25 \mathrm{~mm}\end{array}$ & $\begin{array}{l}249.9 \\
(32.3)\end{array}$ & $\begin{array}{l}119.6 \\
(10.3)\end{array}$ & $\begin{array}{l}1697.3 \\
(133.1)\end{array}$ & $\begin{array}{l}428.9 \\
(28.9)\end{array}$ & $\begin{array}{l}49.1 \\
(4.6)\end{array}$ & $\begin{array}{l}63.6 \\
(5.3)\end{array}$ \\
\hline $\begin{array}{l}0.25- \\
0.05 \mathrm{~mm}\end{array}$ & $\begin{array}{l}317.3 \\
(40.5)\end{array}$ & $\begin{array}{l}242.0 \\
(24.4)\end{array}$ & $\begin{array}{l}1656.7 \\
(156.9)\end{array}$ & $\begin{array}{l}452.0 \\
(23.8)\end{array}$ & $\begin{array}{l}115.3 \\
(7.5)\end{array}$ & $\begin{array}{l}92.6 \\
(13.8)\end{array}$ \\
\hline$<0.05 \mathrm{~mm}$ & $\begin{array}{l}218.9 \\
(47.2)\end{array}$ & $\begin{array}{l}477.8 \\
(36.0)\end{array}$ & $\begin{array}{l}1037.9 \\
(32.9)\end{array}$ & $\begin{array}{l}502.2 \\
(49.0)\end{array}$ & $\begin{array}{l}794.5 \\
(13.6)\end{array}$ & $\begin{array}{l}538.9 \\
(16.7)\end{array}$ \\
\hline
\end{tabular}

Standard deviation values in brackets (headers indicate slope steepness and surface roughness; $T$ tilled, $C$ crusted)

The trends found in net nitrogen losses were completely the same (Table 3 ) as described under net SOC loss.

\section{Table 3}

Net nitrogen losses from various treatments and aggregate classes (mg)

\begin{tabular}{|c|c|c|c|c|c|c|}
\hline & $5(\%) \mathrm{T}$ & $5(\%) C$ & $12(\%) T$ & $12(\%) C$ & $2(\%) I$ & $2(\%) D$ \\
\hline \multicolumn{7}{|l|}{ Period I } \\
\hline$>1.00 \mathrm{~mm}$ & $\begin{array}{l}0.2 \\
(0.02)\end{array}$ & $\begin{array}{l}0.0 \\
(0.00)\end{array}$ & $\begin{array}{l}0.5 \\
(0.04)\end{array}$ & $\begin{array}{l}0.3 \\
(0.09)\end{array}$ & $\mathrm{NA}$ & $\mathrm{NA}$ \\
\hline $\begin{array}{l}1.00- \\
0.25 \mathrm{~mm}\end{array}$ & $\begin{array}{l}6.6 \\
(0.80)\end{array}$ & $\begin{array}{l}2.1 \\
(0.72)\end{array}$ & $\begin{array}{l}19.8 \\
(2.97)\end{array}$ & $\begin{array}{l}2.5 \\
(0.19)\end{array}$ & $\begin{array}{l}0.4 \\
(0.07)\end{array}$ & $\begin{array}{l}0.6 \\
(0.17)\end{array}$ \\
\hline $\begin{array}{l}0.25- \\
0.05 \mathrm{~mm}\end{array}$ & $\begin{array}{l}4.6 \\
(0.87)\end{array}$ & $\begin{array}{l}3.6 \\
(0.09)\end{array}$ & $\begin{array}{l}35.4 \\
(4.42)\end{array}$ & $\begin{array}{l}3.0 \\
(0.51)\end{array}$ & $\begin{array}{l}3.8 \\
(1.13)\end{array}$ & $\begin{array}{l}0.8 \\
(0.10)\end{array}$ \\
\hline$<0.05 \mathrm{~mm}$ & $\begin{array}{l}4.2 \\
(0.64)\end{array}$ & $\begin{array}{l}2.6 \\
(0.32)\end{array}$ & $\begin{array}{l}11.4 \\
(2.95)\end{array}$ & $\begin{array}{l}3.0 \\
(0.19)\end{array}$ & $\begin{array}{l}4.9 \\
(1.21)\end{array}$ & $\begin{array}{l}4.2 \\
(0.58)\end{array}$ \\
\hline \multicolumn{7}{|l|}{ Period II } \\
\hline$>1.00 \mathrm{~mm}$ & $\begin{array}{l}0.0 \\
(0.01)\end{array}$ & $\begin{array}{l}0.04 \\
(0.01)\end{array}$ & $\begin{array}{l}0.5 \\
(0.02)\end{array}$ & $\begin{array}{l}0.1 \\
(0.00)\end{array}$ & $\mathrm{NA}$ & NA \\
\hline
\end{tabular}




\begin{tabular}{|c|c|c|c|c|c|c|}
\hline $\begin{array}{l}1.00- \\
0.25 \mathrm{~mm}\end{array}$ & $\begin{array}{l}4.6 \\
(0.78)\end{array}$ & $\begin{array}{l}1.7 \\
(0.43)\end{array}$ & $\begin{array}{l}17.5 \\
(0.82)\end{array}$ & $\begin{array}{l}3.6 \\
(0.08)\end{array}$ & $\begin{array}{l}0.3 \\
(0.08)\end{array}$ & $\begin{array}{l}0.5 \\
(0.11)\end{array}$ \\
\hline $\begin{array}{l}0.25- \\
0.05 \mathrm{~mm}\end{array}$ & $\begin{array}{l}7.2 \\
(1.35)\end{array}$ & $\begin{array}{l}4.5 \\
(0.61)\end{array}$ & $\begin{array}{l}19.9 \\
(3.23)\end{array}$ & $\begin{array}{l}3.8 \\
(0.43)\end{array}$ & $\begin{array}{l}0.9 \\
(0.43)\end{array}$ & $\begin{array}{l}0.6 \\
(0.33)\end{array}$ \\
\hline$<0.05 \mathrm{~mm}$ & $\begin{array}{l}4.4 \\
(0.48)\end{array}$ & $\begin{array}{l}5.6 \\
(0.40)\end{array}$ & $\begin{array}{l}6.0 \\
(0.19)\end{array}$ & $\begin{array}{l}4.0 \\
(1.98)\end{array}$ & $\begin{array}{l}6.9 \\
(1.98)\end{array}$ & $\begin{array}{l}4.4 \\
(1.39)\end{array}$ \\
\hline \multicolumn{7}{|l|}{ Period III } \\
\hline$>1.00 \mathrm{~mm}$ & $\begin{array}{l}0.1 \\
(0.00)\end{array}$ & NA & $\begin{array}{l}0.6 \\
(0.18)\end{array}$ & $\begin{array}{l}0.3 \\
(0.05)\end{array}$ & NA & NA \\
\hline $\begin{array}{l}1.00- \\
0.25 \mathrm{~mm}\end{array}$ & $\begin{array}{l}2.1 \\
(0.09)\end{array}$ & $\begin{array}{l}2.1 \\
(0.15)\end{array}$ & $\begin{array}{l}25.2 \\
(3.90)\end{array}$ & $\begin{array}{l}4.9 \\
(1.35)\end{array}$ & $\begin{array}{l}0.4 \\
(0.03)\end{array}$ & $\begin{array}{l}0.4 \\
(0.10)\end{array}$ \\
\hline $\begin{array}{c}0.25- \\
0.05 \mathrm{~mm}\end{array}$ & $\begin{array}{l}4.9 \\
(0.47)\end{array}$ & $\begin{array}{l}3.8 \\
(0.73)\end{array}$ & $\begin{array}{l}24.3 \\
(2.11)\end{array}$ & $\begin{array}{l}5.7 \\
(0.40)\end{array}$ & $\begin{array}{l}0.9 \\
(0.38)\end{array}$ & $\begin{array}{l}0.7 \\
(0.04)\end{array}$ \\
\hline$<0.05 \mathrm{~mm}$ & $\begin{array}{l}3.5 \\
(0.49)\end{array}$ & $\begin{array}{l}5.4 \\
(1.38)\end{array}$ & $\begin{array}{l}7.4 \\
(1.40)\end{array}$ & $\begin{array}{l}5.0 \\
(0.08)\end{array}$ & $\begin{array}{l}7.4 \\
(0.98)\end{array}$ & $\begin{array}{l}4.5 \\
(0.33)\end{array}$ \\
\hline
\end{tabular}

Standard deviation values in brackets (headers indicate slope steepness and surface roughness; $T$ tilled; $C$ crusted)

Moreover, this SOC is built by the most acidic and less polymerised organic molecules attached to the smallest mineral particles (Fig. 3 ), making this type of SOC so mobile that it can reach the bottom of the catena or even the surface water without deposition in the field.

\section{Detached soil from the crusted $12 \%$ slope}

In general, a very few amount of aggregates greater than $1.00 \mathrm{~mm}$ were washed down from the crusted surfaces. This sample volume was enough only for SOC and TN analyses but not for spectrophotometric investigations, therefore no value was measured for the aggregates of the biggest size. The spectrophotometric SOM characterisation findings of the $12 \%$ crusted slope represented the same trend as the average did using the $\mathrm{C} / \mathrm{N}$ values. On the basis of $E_{4} / E_{6}$ and $E_{2} / E_{3}$ indexes, the smallest class of aggregates in soil loss has a significantly different SOM compound compared to the bigger aggregates (Fig. 5). The class of the smallest size was characterized by definitely less polymerised organic molecules with lower functional group density than the bigger ones. This phenomenon has been already reported by Rabbi et al. (2014) and Tisdall and Oades (1982); however, their results concerned the in situ cultivated soil. In this case, the SOM quality difference between the smallest and the larger 
aggregates in the in situ, cultivated soil was not found unambiguous.

Therefore, interactions among the aggregates are assumed during splash erosion and sediment delivery processes. SOM compounds of the smallest size are tend to have higher solubility, that is why it is possible that the SOM-clay-mineral interaction occurs after the runoff event, while the samples are kept in still, waiting for total sedimentation.

\section{Fig. 5}

SOM compound measured by spectrophotometric indexes in soil loss of various aggregate size classes (soil loss from $12 \%$ steep crusted surface; $A b s$. absorbance at $280 \mathrm{~nm} ; E_{2} / E_{3}$ and $E_{4} / E_{6}$ indexes; asterisks indicate the in situ soil values)

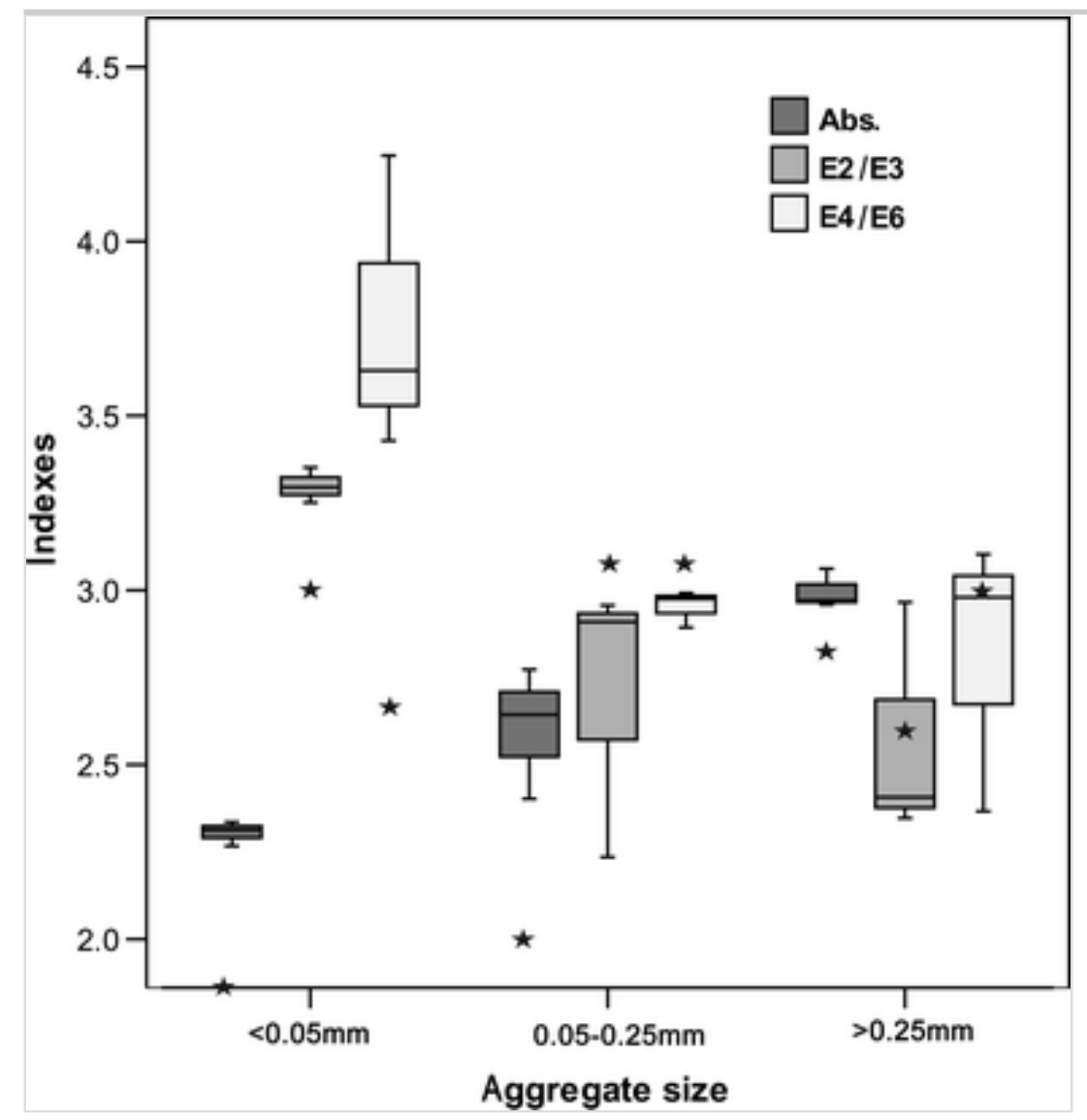

Aromaticity of the soil loss was still proportional to aggregate size, but the values increased by $20 \%$ at each class. Since the SOC amount was increased, the oxidation of the aliphatic components was out of question. The conversion of the aliphatic components to aromatic compounds on the surface of the solid phase did not seem to be probable. Another way might be the selective attachment of the aromatic SOM components to the detached mineral particles. Anyhow, the aromatic character enrichment in soil loss needs special attention for a better understanding. 
In general, no differences were found in mineralogical composition between the sediments of various particle size and the in situ soil. Relevant difference was only found between the soil losses and the in situ soil within the smallest particles (Fig. 6).

\section{Fig. 6}

XRD diffractograms of the $<50 \mu \mathrm{m}$ fraction of soil losses from the crusted $12 \%$ slope (control - in situ soil); D1—runoff from the first period; D2runoff from the second period; and D3 - runoff from the third period

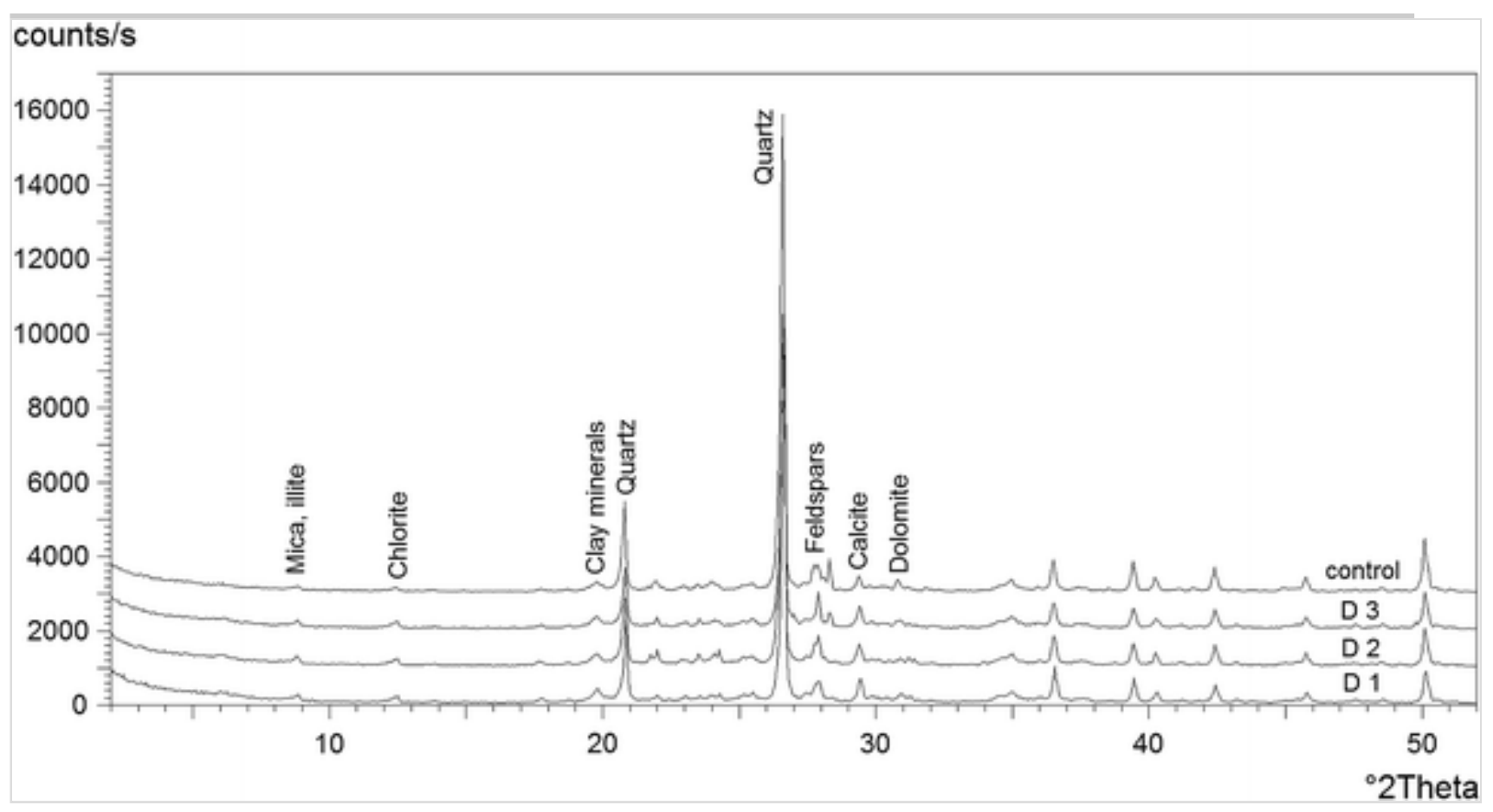

The quartz content of this group decreases due to initial erosion processes. In the detached particles of $<0.05 \mathrm{~mm}$, there is an increased ratio of clay resulted by the loss of quartz independently of the duration of the runoff event. This suggests that it is not the enrichment of unaggregated clay particles but the quartz loss that causes selective clay and SOC erosion. Supposedly, the uncharged quartz with a low surface area is the weakest link within the micro-aggregate which can be loosened and lost during delivery.

\section{Conclusion}

Considerable changes were measured in aggregates SOC concentration and SOM compound of the aggregates. SOC enrichment and the higher ratio of low-molecular-weight, more aromatic SOM components are believed to occur as a result of two parallel processes: (I) chemical degradation of the 
most labile SOM components and (II) mineralogical changes in the smallest aggregate class $(<0.05 \mathrm{~mm})$. Due to splash erosion and sediment delivery processes, the quartz content of the smallest aggregates became considerably lower. Therefore, in the aggregates the ratio of SOC increased; however, the SOC eoncentration amount did not change. The pure quartz cleared from the organic-mineral complexes remained back on the surface because of their higher specific weight. This quartz coverage changed the colour of the soil surface from black to yellow (Fig. 7).

\section{Fig. 7}

Surface characteristics after the 2nd rainfall. Note the appearance of yellowish quartz layer on the surface due to splash erosion. Sulphates moved to the uppermost peaks of the surface and crystallized there by evaporation

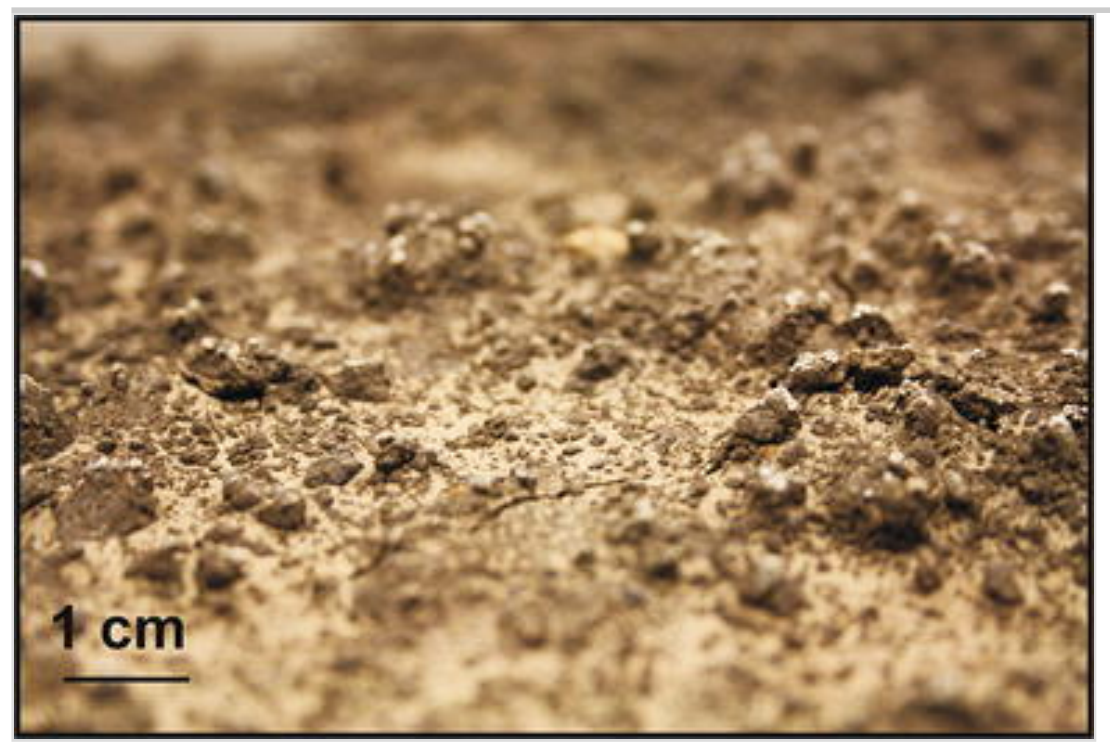

AQ4

The selectivity in detachment mainly referred to the crusted surfaces where it was observed in each treatment. Precipitations over recently tilled soils resulted in the same SOC enrichment in soil loss, but because of the higher surface roughness less compact quartz coverage was found after the runoff.

Initial erosion was studied at point scale; however, due to delivery and deposition processes it is hard to upscale the results. Zhang et al. (2014) stated that it is almost impossible to precisely predict SOC and TN redistribution due to erosion at the field scale because of the complexity of accelerated and tillage erosion processes. Contrarily Wiaux et al. (2014) reported considerable labile SOC enrichment on the backslope and especially in the footslope position. Nevertheless, it was concluded that 
SOM compound is rather the function of absence of pedogenic clay minerals than the result of physical processes during sediment delivery. The higher ratio of SOM of low molecular weight at the footslope does not necessarily mean higher mineralisation potential, since the latter is determined by several other local circumstances as well (Bauer et al. 2012).

In certain circumstances, the classification of soil loss modelled by sieve series can become true in natural landscapes as the spatial classification of aggregates by size. Recently, a field study was carried out in order to compare the modelled findings mentioned above to the real distribution at the hillslope scale. Preliminary results suggest that there are carbon enrichment hotspots with various SOM content regarding the geomorphologic position on the hillslope. Detachment and sedimentation are parts of the same process, but the exact interrelationship between the scales is still far beyond our knowledge.

\section{Acknowledgments}

This study was supported by the Hungarian Scientific Research Fund (OTKA) PD-100929, which is kindly acknowledged here. G. Jakab was supported by the János Bolyai research fellowship by the Hungarian Academy of Sciences. The authors are also grateful to the Egegyümölcs Ltd. for providing the study site. Special thanks to K. Fehér for the laboratory support, L. Bassa, G. Buttafuoco and the unknown reviewers for improving the quality of this study.

\section{References}

Bauer J, Weihermüller L, Huisman JA, Herbst M, Graf A, Séquaris JM, Vereecken H (2012) Inverse determination of heterotrophic soil respiration response to temperature and water content under field conditions. Biogeochemistry 108:119-134

Beguería S, Angulo-Martínez M, Gaspar L, Navas A (2015)

Detachment of soil organic carbon by rainfall splash: experimental assessment on three agricultural soils of Spain. Geoderma 245-246:2130

Bellamy PH, Loveland PJ, Bradley RI, Lark RM, Kirk GJD (2005) 
Carbon losses from all soils across England and Wales 1978-2003. Nature 437:245-248

Bronic CJ, Lal R (2005) Soil structure and management: a review. Geoderma 124:3-22

Burt R, Soil Survey Staff (ed) 2004 Kellogg Soil survey laboratory methods manual. Soil survey investigation report No. 42 USDA NRCS, Lincoln

Buurman P, van Lagen B, Velthorst EJ (eds) (1996) Manual for soil and water analysis. Backhuys, Leiden

Chaplot V, Cooper M (2015) Soil aggregate stability to predict organic carbon outputs from soils. Geoderma 243-244:205-213

Chin YP, Aiken G, Loughlin EO (1994) Molecular weight, polydispersity, and spectroscopic properties of aquatic humic substances. Environ Sci Technol 28:1853-1858

Davidson EA, Janssens IA (2006) Temperature sensitivity of soil carbon decomposition and feedbacks to climate change. Nature 440:165-173

Dövényi Z (ed) (2010) Inventory of microregions in Hungary. MTAFKI Budapest, Hungary In Hungarian

Farsang A, Kitka G, Barta K, Puskás I (2012) Estimating element transport rates on sloping agricultural land at catchment scale (Velence mts., NW Hungary). Carpathian J Earth. Environ Sci 7(4):15-26

Freibauer A, Rounsevell MDA, Smith P, Verhagen J (2004) Carbon sequestration in the agricultural soils of Europe. Geoderma 122(1):1-23

Häring V, Fischer H, Cadisch G, Stahr K (2013) Implication of erosion on the assessment of decomposition and humification of soil organic carbon after land use change in tropical agricultural systems. Soil Biol Biochem 65:158-167 
Hassink J (1997) The capacity of soils to preserve organic C and N by their association with clay and silt particles. Plant Soil 191:77-87

Her N, Amy G, Sohn J, Gunten U (2008) UV absorbance ratio index with size exclusion chromatography (URI-SEC) as an NOM property indicator. J Water Supply 57(1):35-44

Jacinthe PA, Lal R, Owens LB, Hothem DL (2004) Transport of labile carbon in runoff as affected by land use and rainfall characteristics. Soil Tillage Res 77:111-123

Jin K, Cornelis W, Schiette W, Lu J, Buysse T, Baert H, Wu H, Yao Y, Cai D, Jin J, Neve S, Hartmann R, Gabriels D (2008) Redistribution and loss of soil organic carbon by overland flow under various soil management practices on the Chinese Loess Plateau. Soil Use Manag $24: 181-191$

Kahle P, Möller J, Baum C, Gurgel A (2013) Tillage-induced changes in the distribution of soil organic matter and the soil aggregate stability under a former short rotation coppice. Soil Tillage Res 133:49-53

Kemper DW, Rosenau RC (1986) Aggregate stability and aggregate size distribution. In: Klute A (ed) Methods of Soil Analysis Part 1. ASA-SSSA, Madison, pp 425-442

Kirkels FMSA, Cammeraat LH, Kuhn NJ (2014) The fate of soil organic carbon upon erosion, transport and deposition in agricultural landscapes - a review of different concepts. Geomorphology 226:94105

Kuhn NJ, Armstrong EK, Ling AC, Connolly KL, Heckrath G (2012) Interrill erosion of carbon and phosphorus from conventionally and organically farmed Devon silt soils. Catena 91:94-103

Lal R (2004a) Soil carbon sequestration impacts on global climate change and food security. Science 304:1623-1627

Lal R (2004b) Soil carbon sequestration to mitigate climate change.

Geoderma 123(1-2):1-22 
Le Quéré C, Raupach MR, Canadell JG, Marland G (2009) Trends in the sources and sinks of carbon dioxide. Nat Geosci 2:831-836

Liu S, Tan Z, Li Z, Zhao S, Yuan W (2011) Are soils of Iowa USA currently a carbon sink or source? Simulated changes in SOC stock from 1972 to 2007. Agric Ecosyst Environ 140:106-112

Liu MY, Chang QR, Qi YB, Liu J, Chen T (2014) Aggregation and soil organic carbon fractions under different land uses on the tableland of the Loess Plateau of China. Catena 115:19-28

Noponen MRA, Healey JR, Soto G, Haggar JP (2013) Sink or sourcethe potential of coffee agroforestry systems to sequester atmospheric $\mathrm{CO}_{2}$ into soil organic carbon. Agric Ecosyst Environ 175(1):60-68

Quinton JN, Govers G, Van Oost K, Bardgett RD (2010) The impact of agricultural soil erosion on biogeochemical cycling. Nat Geosci 3:311314

Rabbi SMF, Wilson BR, Lockwood PV, Daniel H, Young IM (2014) Soil organic carbon mineralization rates in aggregates under contrasting land uses. Geoderma 216:10-18

Schmidt MWI, Torn MS, Abiven S, Dittmar T, Guggenberger G, Janssens I, Kleberg M, Kogel-Knabner I, Lehmann J, Manning DAC, Nannipieri P, Rasse DP, Weiner S, Trumbore S (2011) Persistence of soil organic matter as an ecosystem property. Nature 478:49-56

Shepherd MA, Harrison R, Webb J (2002) Managing soil organic matter -implications for soil structure on organic farms. Soil Use Manag 18(s1):284-292

Spaccini R, Piccolo A (2013) Effects of field managements for soil organic matter stabilization on water-stable aggregate distribution and aggregate stability in three agricultural soils. J Geochem Explor $129: 45-51$

Stockmann U, Adams M, Crawford JW, Field DJ, Henakaarchchi N, Jenkins M, McBratney AB, de Courcelles VR, Singh K, Wheeler I, 
Abbott L, Angers DA, Baldock D, Bird M, Brookes PC, Chenu C, Jastrow JD, Lal R, Lehmann J, O'Donnell AG, Parton WJ, Whitehead D, Zimmermann M (2013) The knowns, known unknowns and unknowns of sequestration of soil organic carbon. Agric Ecosyst Environ 164(1):80-99

Strauss P, Pitty J, Pfeffer M, Mentler A (2000) Rainfall simulation for outdoor experiments. In: Jamet P, Cornejo J (eds) Current research methods to assess the environmental fate of pesticides. INRA Editions, Idaho Falls, pp 329-333

Su YG, Wu L, Zhou ZB, Liu YB, Zhang YM (2013) Carbon flux in deserts depends on soil cover type. Soil Biol Biochem 58:332-340

Szabó J, Jakab G, Szabó B (2015) Spatial and temporal heterogeneity of runoff and soil loss dynamics under simulated rainfall. Hung Geogr Bull 64(1):25-34

Tan KH (2003) Humic matter in soil and the environment principles and controversies. Marcel Dekker Inc., New York

Tang X, Guan D (2014) Organic carbon stocks and erosion in the soils of Guangdong, South China. Environ Earth Sci 72:2597-2606

Tisdall JM, Oades JM (1982) Organic matter and water stable aggregates in soils. J Soil Sci 33:141-163

Van Oost K, Quine TA, Govers G, De Gryze S, Six J, Harden JW, Ritchie JC, McCarty GW, Heckrath G, Kosmas C, Giraldez JV, Marques da Silva JR, Merckx R (2007) The impact of agricultural soil erosion on the global carbon cycle. Science.

doi:10.1126/science. 1145724

Verma BC, Datta SP, Rattan RK, Singh AK (2013) Labile and stabilized fractions of soil organic carbon in some intensively cultivated alluvial soils. J Environ Biol 34:1069-1075

Wang Z, Govers G, Steegen A, Clymans W, Van den Putte A, Langhans C, Merckx R, Van Oost K (2010) Catchment-scale carbon redistribution 
and delivery by water erosion in an intensively cultivated area.

Geomorphology 124:65-74

Wang Z, Van Oost K, Govers G (2015) Predicting the long-term fate of buried organic carbon in colluvial soils. Glob Biogeochem Cycles. doi:10.1002/2014GB004912

Watteau F, Villemin G, Bartoli F, Schwartz C, Morel J (2012) 0-20 $\mu \mathrm{m}$ aggregate typology based on the nature of aggregative organic materials in a cultivated silty topsoil. Soil Biol Biochem 46:103-114

Wen H, Niu D, Fu H, Kang J (2013) Experimental investigation on soil carbon, nitrogen, and their components under grazing and livestock exclusion in steppe and desert steppe grasslands, Northwestern China. Environ Earth Sci 70(7):3131-3141

Wiaux F, Cornelis JT, Cao W, Vanclooster M, Van Oost K (2014) Combined effect of geomorphic and pedogenic processes on the distribution of soil organic carbon quality along an eroding hillslope on loess soil. Geoderma 216:36-47

World Reference Base for Soil Resources (2007) World soil resources reports No. 103. FAO, Rome

Yamashita T, Flessa H, John B, Helfrich M, Ludwig B (2006) Organic matter in density fractions of water-stable aggregates in silty soils: effect of land use. Soil Biol Biochem 38:3222-3234

Ye X, Tang S, Cornwell WK, Gao S, Huang Z, Dong M, Cornelissen JHC (2015) Impact of land-use on carbon storage as dependent on soil texture: evidence from a desertified dryland using repeated paired sampling design. J Environ Manag 150(1):489-498

Zámbó L, Weidinger T (2006) Investigations of karst corrosional soil effects based on ranfall simulation experiment. In: Kiss A, Mezősi G, Sümeghy Z (eds) Táj, környezet és társadalom. Ünnepi tanulmányok Keveiné Bárány Ilona professzor asszony tiszteletére, Szeged, pp 757765 (In Hungarian) 
Zhang S, Zhang X, Liu Z, Sun Y, Liu W, Dai L, Fu S (2014) Spatial heterogeneity of soil organic matter and soil total nitrogen in a Mollisol watershed of Northeast China. Environ Earth Sci 72(1):275-288 